$\stackrel{\odot}{\text { III }}$

\title{
MATEMATYKA KULTURY, CZYLI JAK POLICZYĆ CHARAKTER KULTUROWY MIASTA?
}

\begin{abstract}
Marta Klekotko, Matematyka kultury, czyli jak policzyć charakter kulturowy miasta? [Mathematics of culture: how to measure cultural character of a city?] edited by M. Nowak ${ }_{\prime \prime}$ Człowiek i Społeczeństwo" vol. XLVIII: Kuchnia badań miejskich. Studia na temat praktyki empirycznej badaczy miasta [A backstage of urban research. Studies on the empirical practices of city research scientists], Poznań 2019, pp. 13-34, Adam Mickiewicz University. ISSN 0239-3271.
\end{abstract}

The purpose of the article is to critically discuss the methodology for measuring "urban scenes" which has been proposed by contemporary Chicago School. The author presents the assumptions and conceptual-analytical framework of scene theory, and then discusses the consecutive steps of the research strategy developed by this theory. The author refers to her research experience in using the scene approach and points to challenges and problems in the application of the scene theory, as well as proposes some strategies of overcoming them.

Marta Klekotko, Uniwersytet Jagielloński, Instytut Socjologii UJ, ul. Grodzka 52, 31-044 Kraków, e-mail: marta.klekotko@uj.edu.pl

\section{Liczenie kultury - wprowadzenie}

To, że kultura ma znaczenie, nie ulega dziś najmniejszej wątpliwości. Nie mają co do tego wątpliwości także badacze miasta, o czym świadczy niesłychany w ostatnich dekadach przyrost prac w zakresie tzw. kulturowych studiów miejskich (por. m.in. Florida, 2002a, b, c; Judd i Fainstein, 1999; Zukin, 1995, Page, 1995; Brooks, 2000; Gieryn, 2000; Glaeser, Kolko i Saiz, 2001; Chatterton i Hollands, 2002; Clark, 2003a, 2007; Landry, 2006a, b; Borer, 2006, Markusen, 2006; Lloyd, 2007 itp.). Kultura, jak się wydaje, wyjaśnia 
coraz więcej, wypierając nieraz „tradycyjne” zmienne wyjaśniające, takie jak wiek, płeć czy status ekonomiczny (por. Clark, 2003a). Niestety, przyrostowi prac podejmujących wątek szerokich oddziaływań kultury na życie i rozwój miast nie towarzyszy wystarczająca refleksja metodologiczna. Badania prowadzone w ramach kulturowych studiów miejskich nie pozwalają na ogół na porównania i systematyczne obserwacje trendów, a tym samym nie dają nadziei na wypracowanie twierdzeń poddających się weryfikacji. Dlatego wypracowanie metod opisu, które umożliwiłyby systematyczne porównania miast, jest dziś jednym z najpilniejszych wyzwań kulturowych studiów miejskich (Kaple, Morris, Riukin-Fush i Dimaggio, 1996; Rothfield, 1999; Schuster, 2002; Lucchini, 2002). Najczęściej praktykowaną strategią jest zliczanie różnego rodzaju wybranych na podstawie przyjętej koncepcji walorów czy obiektów w mieście (tzw. amenities), a następnie obliczanie wskaźników ich koncentracji i zagęszczenia na danym terytorium, by w ten sposób określić różne typy przestrzeni.

Tak powstałe typologie służą zwłaszcza studiom nad rozwojem miasta (tzw. amenity-driven urban development), poszukującym statystycznie istotnych związków między liczbą poszczególnych typów walorów miejskich a wskaźnikami wzrostu. Richard Florida (2002c) wykazał, że długość ścieżek rowerowych koreluje ze wzrostem gospodarczym. Ann Markusen (2006) analizowała wpływ artystów, a Edward Glaeser, Jed Kolko i Albert Saiz (2001) ustalili, że miasta, które rozwijają się szybciej, to te o dużym zagęszczeniu miejskich walorów, dobrej pogodzie, atrakcyjnym otoczeniu i wysokiej jakości usługach publicznych. Terry Clark (2003b; Clark, Lloyd, Wong i Jaiun, 2001) ustalał związki między określonymi grupami walorów miejskich a charakterystykami demograficznymi mieszkańców, dowodząc, że zmiany charakteru przestrzeni miejskiej prowadzą do migracji. Te przykładowe ustalenia na temat oddziaływań kultury na rozwój miast wydają się jednak mieć dość ograniczony charakter i nie wyjaśniają istoty kulturowych mechanizmów rozwoju. Nie traktują one miasta i kultury miejskiej holistycznie, jako dynamicznego systemu elementów połączonych złożonymi relacjami, przez co mają ograniczoną wartość wyjaśniającą. Potrzebujemy narzędzi, które pozwoliłyby na całościowy opis i pomiar dynamiki kulturowej miasta, które dostarczyłyby wyjaśnień i ustaliły uniwersalne prawidłowości i logikę działania miasta poprzemysłowego. Na te właśnie potrzeby stara się odpowiedzieć tzw. teoria scen, rozwijana przez współczesną szkołę chicagowską (Navarro, Guerrero, Mateos i Muñoz, 2012; Silver, Clark i Graziul, 2011; Klekotko i Navarro, 2015; Silver i Clark, 2016). Niniejszy artykuł stanowi krytyczne omówienie założeń tej teorii oraz jej możliwych zastosowań. 
Artykuł składa się z czterech części. W pierwszej dokonuję prezentacji założeń teorii scen, w tym zwłaszcza „wymiarów kulturowych” sceny, nazywanych przez twórców teorii „gramatyką sceny”. Dalej przedstawiam założenia ilościowego pomiaru miejskich scen kulturowych, a więc tzw. „matematykę scen”. W części trzeciej dokonuję omówienia słabości proponowanego ujęcia oraz trudności jego aplikacji w warunkach polskich. Dzielę się również swoimi doświadczeniami w próbach przezwyciężania napotkanych w procesie badawczym ograniczeń. Opracowanie kończę wskazaniem kierunków rozwoju analizowanego podejścia.

\section{Gramatyka kultury, czyli założenia teorii scen}

Aby przekroczyć wspomniane ograniczenia dotychczasowych podejść w badaniu charakteru kulturowego miasta, teoria scen wychodzi od trzech podstawowych założeń epistemologicznych. Są nimi: holizm, relacyjność i kontekstowość pomiaru miejskiej kultury. Odrzuca się zatem strategię zliczania pojedynczych amenities, zastępując ją holistycznym pojęciem sceny, w której rozmaite walory miejskie wchodzą z sobą w rozmaite relacje, tworząc w ten sposób specyficzny społeczno-kulturowy kontekst znaczeniowy. I to właśnie owe holistyczne społeczno-kulturowe konteksty powinny być przedmiotem badań, a nie pojedyncze i jako takie pozbawione społecznego sensu walory.

Scenę miejską definiuje się jako dynamiczny układ (1) otoczenia fizycznego oraz (2) ludzi, (3) realizujących praktyki konsumpcji kulturowej, (4) które odznaczają się określonymi wartościami i symbolicznymi znaczeniami (Silver i in., 2011; por. Klekotko, Navarro, Silver i Clark, 2015; Silver i Clark, 2016). Scena miejska jest więc przestrzenią naznaczonych symbolicznie praktyk kulturowej konsumpcji. Tak rozumianą scenę można opisać za pomocą trzech wymiarów tworzących specyficzną kombinację symbolicznych wartości, które leżą u podłoża podejmowanych w nich praktyk kulturowej konsumpcji i tym samym czynią je społecznie znaczącymi: uprawomocnienie, teatralność i autentyczność.

Wymiar uprawomocnienia pozwala opisać wartości i motywy, które kierują praktykami konsumpcji kulturowej i uprawomocniają je. Wyznacza on właściwe i pożądane style życia, określa, które sposoby postępowania są dobrze, a które źle postrzegane. Źródłem uprawomocnienia wzorów konsumpcji mogą być: tradycja (gdy jednostka robi to, co uważa za zgodne z tradycja), charyzma (gdy pożądane zachowania narzucane są przez sławne bądź charyzmatyczne 
jednostki lub autorytety), autoekspresja (gdy uzasadnieniem działania jest prawo każdego do wyrażania siebie i doświadczania niepowtarzalnych doznań), egalitaryzm (gdy uprawnionymi działaniami są te, do których wszyscy mają równy dostęp) albo utylitaryzm (gdy za słuszne uważane jest to, co jest przede wszystkim użyteczne).

Wymiar teatralności pozwala opisać charakter ról, jakie uczestnicy sceny odgrywają nawzajem przed sobą, a więc to, jak chcą być postrzegani i w jaki sposób postrzegają innych. Wyróżnia się pięć wymiarów teatralności: sąsiedzkość (działania oparte na zażyłych, „swojskich” i bliskich relacjach), transgresja (gdy chcemy pokazać się innym jako ci, którzy przekraczają obowiązujące powszechnie normy i wzory zachowań), ekshibicjonizm (gdy zależy nam na tym, by być „widocznymi” i podziwianymi przez innych), szyk (glamour - gdy celem jednostki jest odgrywanie roli trendsettera, narzucanie innym trendów i uchodzenie za osobę „modną”) oraz formalność (gdy istotnym elementem działania jest przestrzeganie ścisłych reguł i zasad lub etykiety).

Wymiar autentyczności rozumiany jest jako „istotne poczucie tożsamości” i pozwala opisać treść tożsamości wyrażanych i realizowanych w praktykach kulturowej konsumpcji. Każdy akt kulturowej konsumpcji jest w istocie wyrazem określonej tożsamości i prowadzi do samorealizacji jednostki. Działający na danej scenie aktor może budować swoją tożsamość na podstawie wartości i tradycji lokalnych (wymiar lokalizmu), pochodzenia etnicznego (etniczność), wartości korporacyjnych (korporacyjność), obywatelstwa (państwowość) bądź przekonania o wyższości racjonalnych podstaw tożsamości jednostkowej (racjonalizm).

Tabela 1. Gramatyka scen: wymiary scen miejskich

\begin{tabular}{|l|l|l|}
\hline \multicolumn{1}{|c|}{ Uprawomocnienie } & \multicolumn{1}{c|}{ Teatralność } & \multicolumn{1}{c|}{ Autentyczność } \\
\hline tradycja & sąsiedzkość & lokalność \\
\hline ekspresja & transgresja & etniczność \\
\hline charyzma & ekshibicjonizm & państwo \\
\hline utylitaryzm & glamour & korporacja \\
\hline egalitaryzm & formalność & racjonalizm \\
\hline
\end{tabular}

Źródło: opracowanie własne na podstawie Silver i in., 2011.

Wymienione wymiary uprawomocnienia, teatralności i autentyczności występują w różnych konfiguracjach, tworząc w ten sposób odmienne sceny, a każda z nich pozwala uczestniczącym w nich jednostkom praktykować odmienny styl życia, realizować odmienne wartości i budować 
odmienną tożsamość. Połączenie autoekspresyjnego uprawomocnienia, transgresyjnej teatralności z lokalną, antyracjonalną i antykorporacyjną autentycznością tworzy scenę bohemistyczną, podczas gdy sąsiedzka teatralność, tradycyjne uprawomocnienia i lokalna autentyczność - scenę komunitarną (Silver i Clark, 2016). Istnieje wiele konkretnych rodzajów scen, takich jak „Scena LaLa Land”, „Scena Disney Heaven”, „Baudelaire’s River Styx”, z których każda charakteryzuje się konkretną kombinacją wartości. Różne jednostki, o różnych tożsamościach społecznych, kierują się odmiennymi motywami i odgrywają odmienne role, dlatego poszukiwać będą odmiennych scen.

\section{Matematyka kultury, czyli strategia pomiaru scen}

Jednym z podstawowych celów badaczy scen jest ilościowy pomiar charakteru kulturowego miasta, który pozwalałby na testowanie hipotez o makroprocesach społecznych, umożliwiał prowadzenie systematycznych analiz i gwarantował porównywalność wyników badań. Rozwinięto wobec tego strategię nazywaną „matematyką sceny”, która pozwala przełożyć ulotne wartości i wrażenia kulturowe na poddające się statystycznym analizom liczby: z przedstawionych piętnastu wymiarów scen tworzy się pięciostopniowe skale, na których następnie lokuje się występujące na danym terenie obiekty, przypisując im odpowiednią wagę. Waga 5 oznacza, że zdefiniowane przez skalę wartości stanowią istotę bytu danego obiektu, że istnieje on właśnie po to, by jednostki mogły te wartości w nim realizować. Waga 4 oznacza z kolei, że dany obiekt służy realizacji tych wartości, ale nie stanowią one najważniejszego aspektu jego funkcjonowania i nie przesądzają o jego istocie. Obiektom, które służą realizacji wartości przeciwnych do tych zdefiniowanych przez skalę, ale nie wykluczają ich całkowicie, przypisujemy wagę 2 . Gdy w danym obiekcie jednostki realizują wartości będące zaprzeczeniem wartości zdefiniowanych przez daną skalę i wykluczają je, przypisujemy im wagę 1 . Wagę 3 nadajemy tym obiektom, które nie wykazują żadnego związku z analizowaną wartością, to znaczy ani nie stanowi ona aspektu ich funkcjonowania, ani dany obiekt jej nie zaprzecza. W przypadkach, gdy dany obiekt nie daje się zdefiniować, przypisujemy mu wagę 99 i wykluczamy z obliczeń.

Podstawową miarą w przyjętej strategii jest Performance Score (PfS), który jest sumą iloczynów liczby obiektów określonego typu i nadanej mu na danej skali (wymiarze) wagi, podzieloną przez całkowitą liczbę 


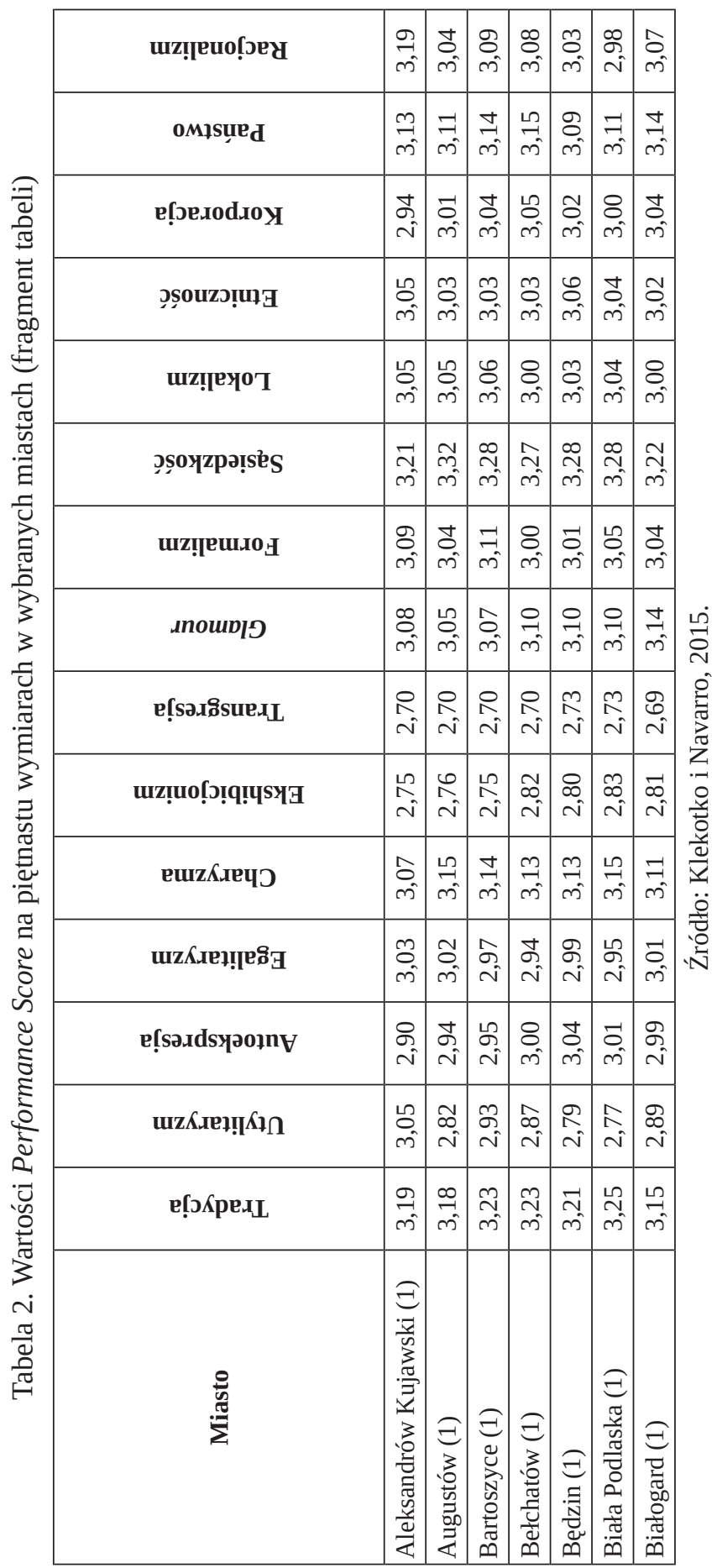


wszystkich obiektów uwzględnionych w analizie. Wartości PfS mieszczą się w przedziale od 1 do 5 i informują nas o „sile” badanego wymiaru w charakterze danej przestrzeni, który jest wynikiem oddziaływania wartości i znaczeń wszystkich zlokalizowanych w niej obiektów. Jeśli zatem chcielibyśmy określić, na ile dane miasto lub jakiś jego fragment wyraża wartości „transgresyjne”, nasze postępowanie przebiegałoby w następujący sposób: (1) wszystkim obiektom przypisalibyśmy odpowiednią wartość na skali „transgresja”, (2) przemnożylibyśmy liczbę obiektów każdego typu przez przydzieloną mu wartość, (3) dodalibyśmy wszystkie iloczyny do siebie i na końcu (4) podzielili otrzymaną sumę iloczynów przez całkowitą liczbę wszystkich obiektów. Wyobraźmy sobie, że w badanej przez nas jednostce przestrzennej X znajdują się: jeden kościół, jeden salon tatuażu, dwa domy publiczne i jeden żłobek. Łącznie mamy pięć obiektów (całkowita liczba obiektów). Każdy z nich otrzymał w procesie kodowania określoną wagę. Przyjmijmy, że przyznaliśmy następujące wartości: kościół - 1, salon tatuażu - 5, dom publiczny -5 , żłobek -2 . Po przemnożeniu liczby obiektów każdego typu przez przypisaną im wartość otrzymujemy następujące iloczyny: $1 \times 1=1,1 \times 5=5,2 \times 5=10,1 \times 2=2$. Suma tych iloczynów wynosi $1+5+10+2=18$. Teraz pozostaje podzielić sumę iloczynów (18) przez całkowitą liczbę obiektów (5) i otrzymujemy Performance Score wymiaru transgresji: 3,6.

Uzyskawszy Performance Score każdego wymiaru, możemy przejść do bardziej złożonych analiz i opisu charakteru kulturowego badanych miast. Do podstawowych narzędzi takiego opisu należą profile, wymiary i typy kulturowe miasta (Navarro i in., 2012; Klekotko i Navarro, 2015; Klekotko, i in., 2015). Najprostszą formą opisu jest określenie profilu kulturowego miasta. W tym celu zestawiamy wartości PfS osiągnięte przez dane miasto i interpretujemy współwystępowanie wysokich/niskich wartości PfS na poszczególnych wymiarach. Porównując profile kilku miast (lub kilku dzielnic w ramach jednego miasta), możemy określić, czym dane miasto (lub dzielnica) wyróżnia się na tle innych. W tym celu dobrze jest przeprowadzić centrowanie wyników PfS względem średniej dla danej grupy i przeanalizować odchylenia wyników uzyskanych przez porównywane miasta (dzielnice) na poszczególnych wymiarach. Średnia dla danej grupy przyjmuje wtedy wartość zero, a różnice między porównywanymi miastami ilustruje ich położenie względem zera. Wartości dodatnie świadczą o tym, że dane miasto odróżnia się od badanej reszty pod danym względem in plus, wartości ujemne pokazują natomiast, że w porównaniu z innymi w danym mieście określone formy konsumpcji są mniej obecne. 


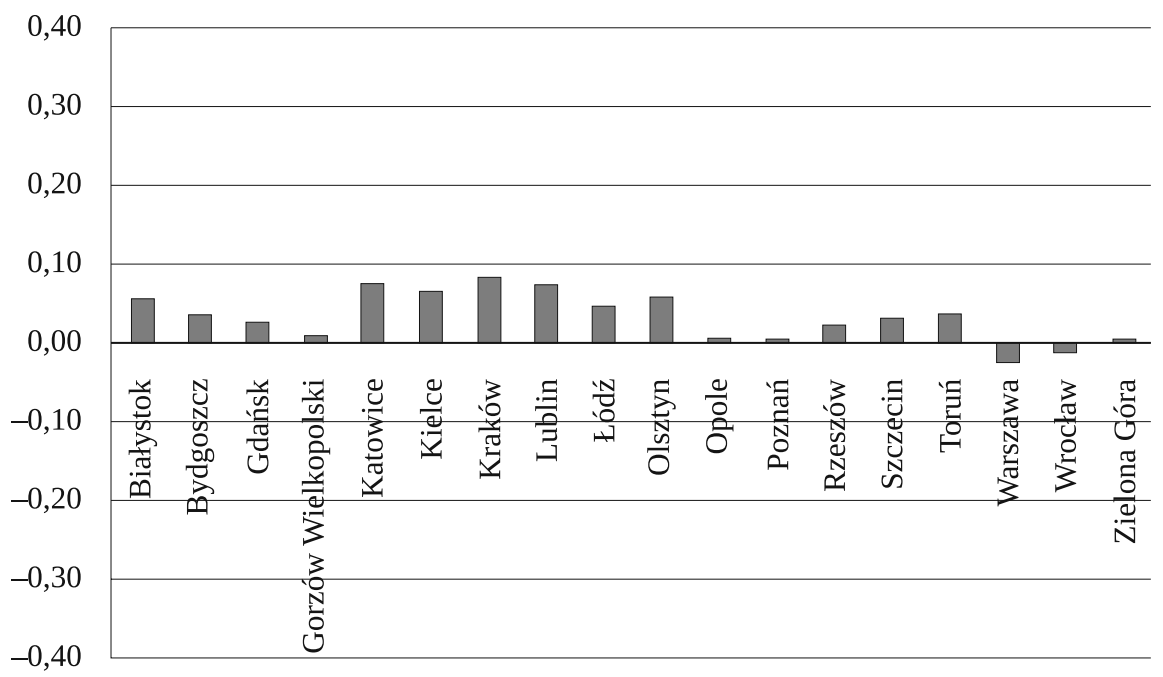

Rysunek 1. Wartości odchyleń od średniej PfS na wymiarze „Tradycja” dla osiemnastu największych polskich miast Źródło: Klekotko i Navarro, 2015.

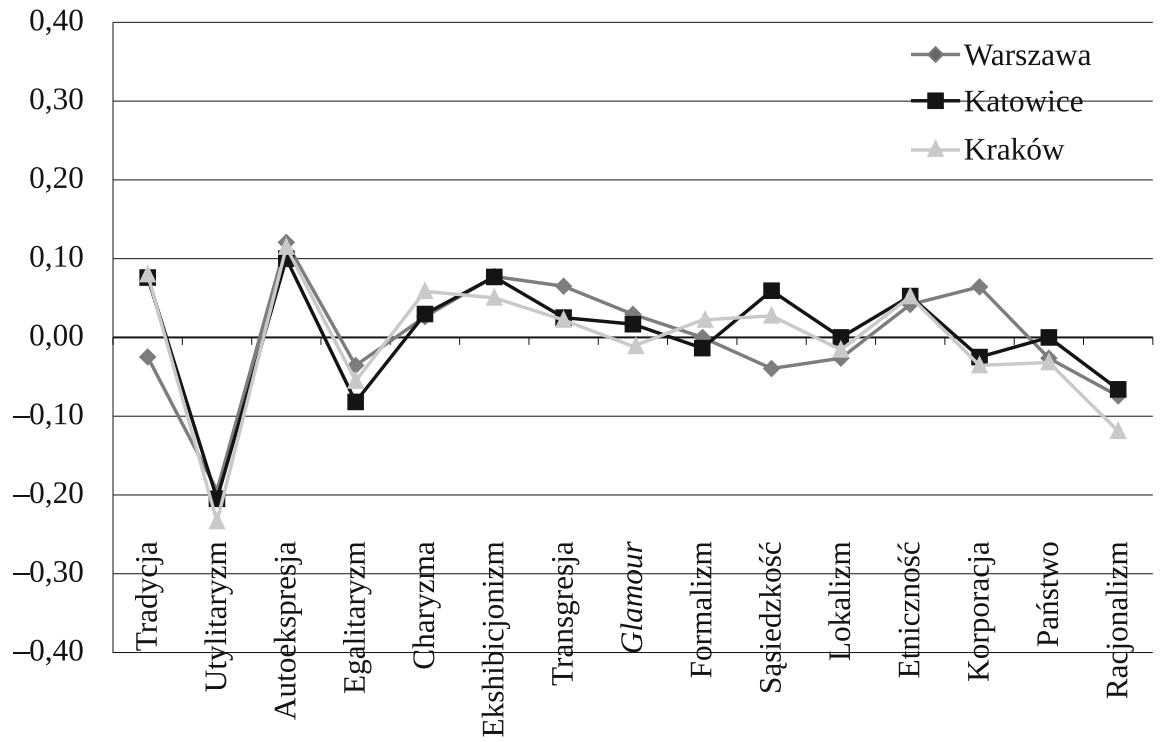

Rysunek 2. Profile kulturowe Katowic, Krakowa i Warszawy

(wyliczone na podstawie odchyleń od średnich PfS dla osiemnastu największych miast w Polsce) Źródło: Klekotko i Navarro, 2015. 
Inną możliwą formą opisu jest identyfikacja wymiarów kulturowych miasta. W tym celu przeprowadza się analizy głównych składowych z wykorzystaniem wartości PfS osiągniętych przez badane miasta na poszczególnych skalach. W wyniku analizy otrzymuje się syntetyczne wymiary, stanowiące swoiste konglomeraty skal. W ten sposób kilkanaście skal zostaje zastąpionych przez niewielką liczbę (2-4) kulturowych wymiarów, z których każdy wyraża określoną kombinację wartości. Dowiadujemy się dzięki temu, jakie wartości w największym stopniu odpowiadają za zróżnicowanie badanych miast. Zabieg ten pozwala określić główne osie zróżnicowania miast i ich położenie względem siebie. Innymi słowy każde miasto otrzymuje w wyniku analizy określoną wartość czynnikową, ilustrującą usytuowanie badanego przypadku w macierzy wyznaczanej przez zidentyfikowane wymiary, która może posłużyć nam do porównań z innymi miastami.

Tabela 3. Wyniki analizy głównych składowych wymiaru „Uprawomocnienie” w polskich gminach miejskich oraz wyniki łącznej analizy głównych składowych „Uprawomocnienia”, „Teatralności” i „Autentyczności” z wykorzystaniem głównych składowych uzyskanych w wyniku analiz dla każdego z tych wymiarów z osobna (wyszczególnione w pierwszej kolumnie drugiej tabeli)

\begin{tabular}{|l|c|c|}
\hline \multirow{2}{*}{ Uprawomocnienie } & \multicolumn{2}{c|}{ Składowa } \\
\cline { 2 - 3 } & $\mathbf{1}$ & $\mathbf{2}$ \\
\hline Tradycja & 0,007 & 0,941 \\
\hline Utylitaryzm & 0,842 &,- 307 \\
\hline Autoekspresja &,- 939 &,- 059 \\
\hline Egalitaryzm & 0,642 &,- 496 \\
\hline Charyzma &,- 499 & 0,672 \\
\hline Procent wyjaśnionej wariancji & 45 & 33,6 \\
\hline Skumulowany procent wyjaśnionej wariancji & 45 & 78,6 \\
\hline
\end{tabular}

\begin{tabular}{|l|c|c|}
\hline \multirow{2}{*}{\multicolumn{1}{c|}{ Sceny kulturowe - analiza lączna }} & \multicolumn{2}{c|}{ Składowa } \\
\cline { 2 - 3 } & $\mathbf{1}$ & $\mathbf{2}$ \\
\hline Utylitaryzm + egalitaryzm ↔ Ekspresja + charyzma & 0,937 & 0,037 \\
\hline Tradycja + charyzma ↔ Egalitaryzm & 0 & 0,918 \\
\hline Ekshibicjonizm + transgresja + szyk ↔ Formalizm &,- 849 &,- 256 \\
\hline Swojskość ↔ Szyk &,- 213 & 0,838 \\
\hline Państwowość + racjonalizm ↔ Etniczność & 0,771 &,- 326 \\
\hline Lokalizm ↔ korporacjonizm & 0,367 & 0,672 \\
\hline Procent wyjaśnionej wariancji & 39,5 & 36,1 \\
\hline Skumulowany procent wyjaśnionej wariancji & 39,5 & 75,6 \\
\hline
\end{tabular}

Źródło: Klekotko i Navarro, 2015. 
Wreszcie trzecią formą opisu jest identyfikacja typu kulturowego miasta. W tym celu przeprowadza się analizę skupień, wykorzystując w niej jako zmienne wartości czynnikowe otrzymane w wyniku analiz głównych składowych. Uchwycone w analizach czynnikowych wymiary tworzą macierz, w której ulokowane są wszystkie badane miasta. Analiza skupień polega na pogrupowaniu tych miast w pewne typy na podstawie ich podobnego położenia względem wyznaczonych osi (wymiarów). Analiza skupień pozwala tym samym w empiryczny sposób zidentyfikować określone typy miast cechujących się podobną konfiguracją wartości. Jej wynikiem jest typologia miast, a więc najbardziej syntetyczna forma opisu, która pod nazwą typu gromadzi układającą się we wzór wielość znaczeń. Tak uchwycone typy można następnie opisywać i charakteryzować, poszukując ich profilu społeczno-demograficznego lub gospodarczego, a także szukać korelacji z różnego rodzaju fenomenami społeczno-politycznymi.

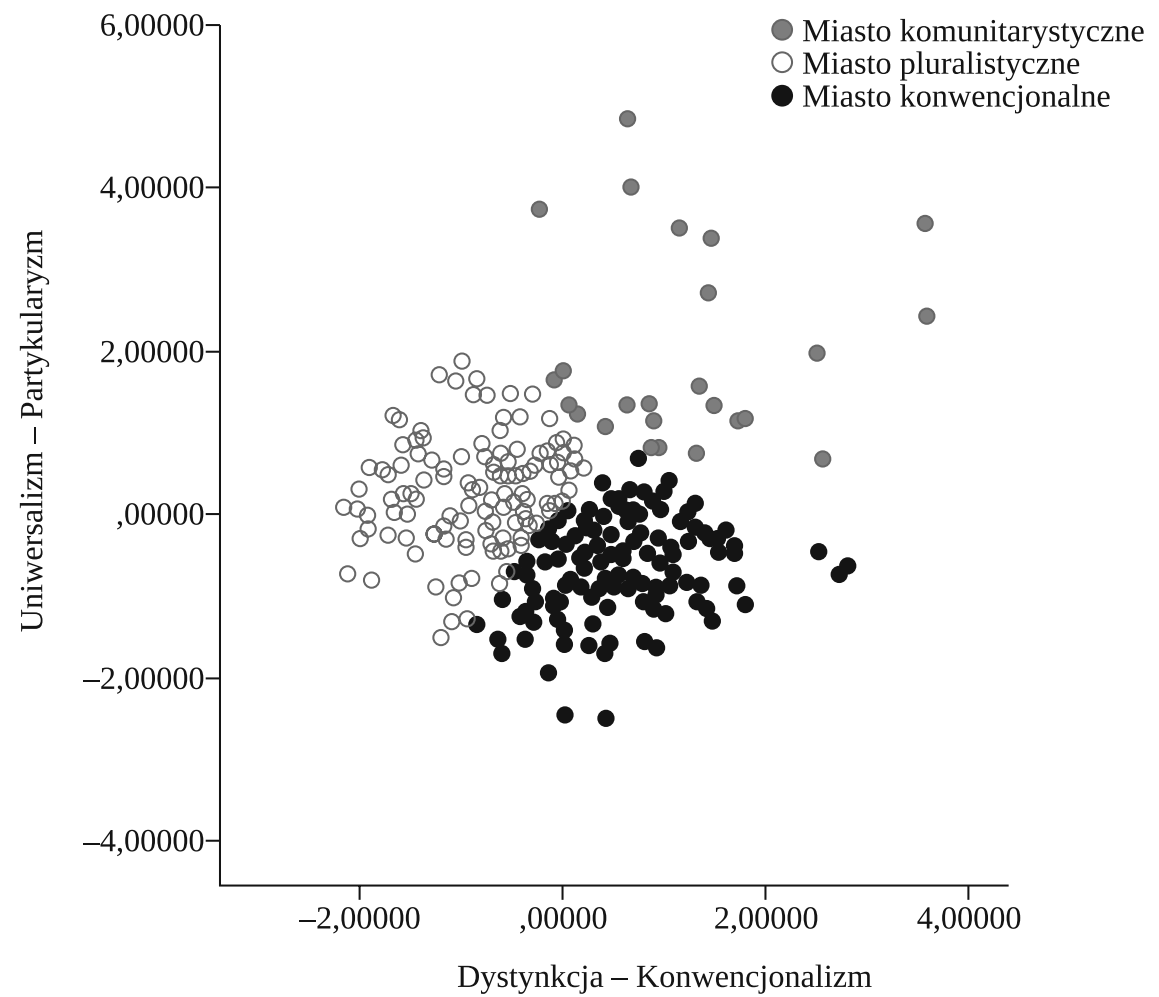

Rysunek 3. Analiza skupień z wykorzystaniem głównych składowych identyfikacja typów kulturowych

Źródło: Klekotko i Navarro, 2015. 


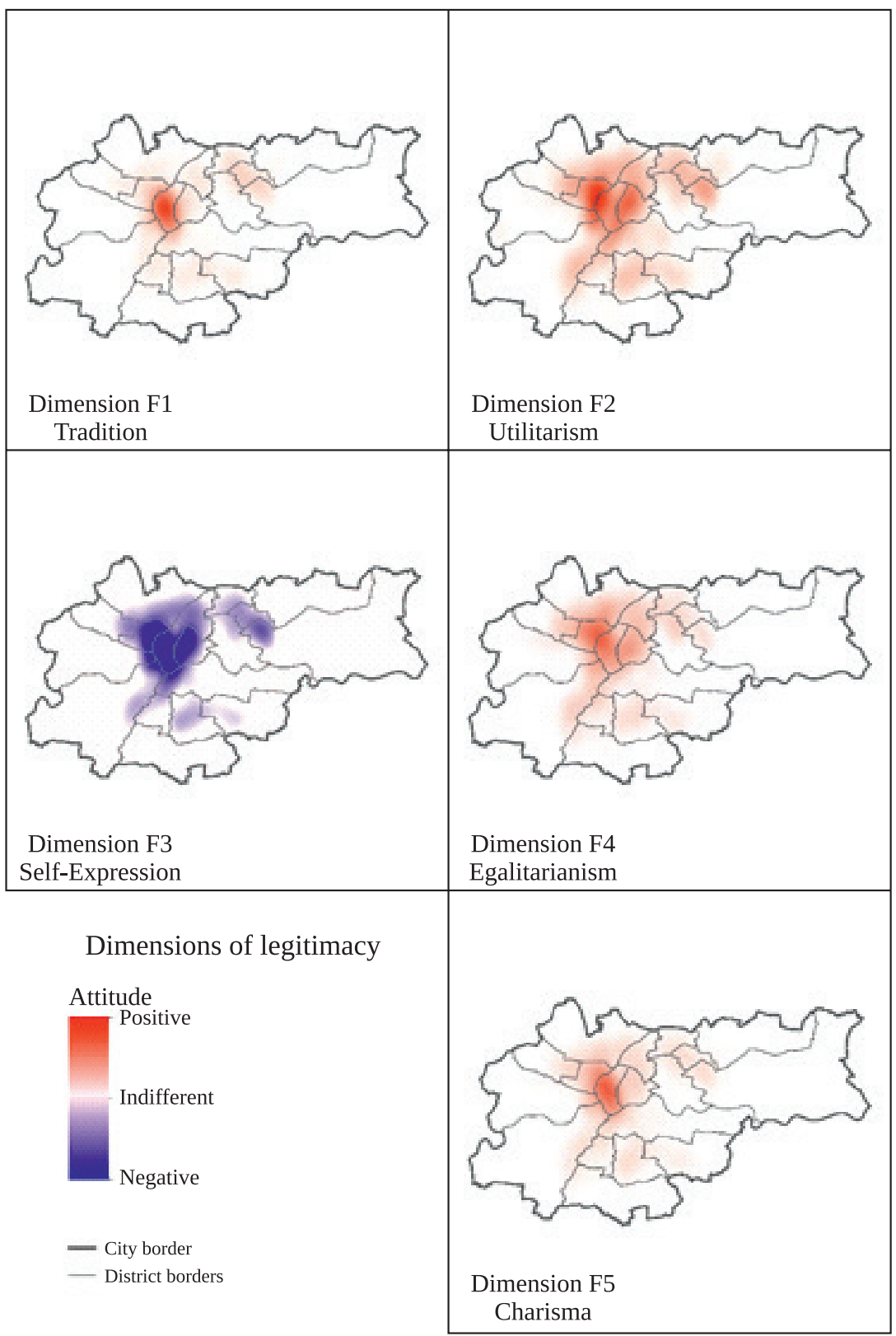

Rysunek 4. Rozkład wartości Performance Score wymiarów uprawomocnienia w Krakowie - wizualizacja analiz przestrzennych z wykorzystaniem oprogramowania GIS Źródło: Klekotko i Navarro, 2015. 
Zarówno obliczenia Performance Score, jak i wszystkie oparte na nich formy opisu charakteru kulturowego miejskiej przestrzeni można przeprowadzić z wykorzystaniem oprogramowania geokodującego i analiz geoprzestrzennych. Opisane miary oblicza się dla zdefiniowanych wcześniej jednostek przestrzennych, a wyniki prezentuje na mapach, które w wyjątkowo czytelny sposób pozwalają oddać kulturowe zróżnicowanie badanej przestrzeni. Przykłady omówionych form opisu zawarto w tabelach 2-3 i na rycinach 1-4.

\section{Diabeł tkwi w szczegółach: wyzwania i problemy aplikacji teorii scen}

Niezwykle przemyślana i atrakcyjna konceptualnie teoria scen, a także prosta i czytelna strategia ich pomiaru okazuje się bardziej skomplikowana, niżby się wydawało, kiedy przychodzi do jej zastosowania w warunkach innych niż amerykańskie (por. Klekotko i Navarro, 2015; 2018). Chcąc wykorzystać rozwinięte przez Silvera i Clarka podejście, badacz staje przed wieloma ważnymi decyzjami metodologicznymi, które zdeterminują wyniki podjętych analiz. Do najważniejszych należy przede wszystkim decyzja o doborze zmiennych i źródeł danych o nich, nadaniu każdej zmiennej odpowiednich wag na przyjętych skalach oraz wyborze jednostki analizy, dla której będzie się wykonywało obliczenia zaproponowanych wcześniej miar. Jak widzieliśmy, wartość Performance Score determinowana jest dwoma elementami: liczbą wybranych do analizy typów obiektów oraz przypisanymi im wagami. Manipulując zestawem obiektów lub wagami, zmieniamy PfS. Z kolei zestaw i liczba obiektów zależeć będą od tego, jak dużą przestrzennie jednostkę analizy wybierzemy. Z tego też powodu wybór odpowiedniej jednostki oraz dobór obiektów do analizy i ich zakodowanie należy uznać za kluczowe dla całej analizy.

Teoria scen nie określa, jakiego typu obiekty należy uwzględnić w analizie, dlatego przyjąć można jedną z dwóch strategii: uwzględnić w analizie wszystkie obiekty albo wybrać tylko niektóre z nich. O ile pierwsze rozwiązanie jest „,bezpieczniejsze” ze względu na obiektywizm (unikamy arbitralnego i siłą rzeczy subiektywnego doboru zmiennych przez badacza), o tyle drugie okazuje się bardziej „czułe” na obecność poprzemysłowych trendów kulturowych (unikamy bowiem „rozmycia” efektu praktyk konsumpcji o wyraźnym charakterze w morzu praktyk bez takiegoż charakteru). Wybór odpowiedniej strategii należy uzależnić od charakteru dostępnych danych oraz specyfiki gospodarczej i kulturowej badanego społeczeństwa. Mając do dyspozycji bogate, dokładne i szczegółowe dane, możemy zdecydować się na pierwsze 
rozwiązanie, w przeciwnym razie lepiej jest dokonać selekcji zmiennych. Jeśli zatem posiadamy dane na temat ekologicznych gospodarstw rolnych, rolnej produkcji subskrypcyjnej czy rolnictwa obywatelskiego, pewne cechy kultury poprzemysłowej moglibyśmy uchwycić nawet w tak mało poprzemysłowym sektorze, jakim jest produkcja rolna. W społeczeństwach mniej zaawansowanych pod względem procesów modernizacyjnych zastosowanie takiej metody okazałoby się jednak zgubne - nie tylko tego typu podmiotów jest zbyt mało, by móc je uchwycić w całej masie innych, ale - ze względu właśnie na ich rzadkość - statystyki publiczne nie dostarczają jeszcze tego typu kategorii klasyfikacji. Dlatego w przypadku takich miast jak polskie warto zdecydować się na drugą strategię. Stajemy wtedy przed problemem wyboru odpowiedniego zestawu zmiennych, a więc decyzji, jakiego rodzaju praktyki kulturowej konsumpcji (których wskaźnikami będą konkretne typy działalności gospodarczej) będziemy brali pod uwagę w określaniu charakteru kulturowego miasta.

Ustalenie wyraźnej linii demarkacyjnej jest niezwykle trudne, jeśli nie niemożliwe. Tworząc listę obiektów, a właściwie wybierając obiekty z dostępnych baz danych, należy kierować się zarówno teoriami społeczeństw poprzemysłowych, jak i samą teorią scen i dobierać najbardziej „nośne” konceptualnie obiekty. Produkcja samochodów prawdopodobnie nie będzie miała takiego znaczenia dla kreacji poprzemysłowych scen miejskich jak produkcja oprogramowania, dlatego nie uwzględnimy w analizach fabryki samochodów, ale weźmiemy pod uwagę firmy softwarowe. Warto jednak wstępnie wybrać więcej obiektów, a następnie, już po wstępnym zakodowaniu, kiedy okaże się, które obiekty rozmywają obraz i nie wnoszą wiele do obrazu kulturowego, dokonać selekcji zmiennych (dla przykładu: w polskich badaniach uwzględniono początkowo ponad 1000 zmiennych, a po oczyszczeniu i zakodowaniu obiektów zakwalifikowano do analizy ostatecznie 295 kategorii).

Tworząc Bazę Obiektów, a więc zbierając dane na temat liczebności obiektów różnego typu w badanych miastach, należy podjąć decyzję o wielkości jednostek przestrzennych, które będziemy analizować, oraz o źródle i szczegółowości danych, które wykorzystamy. Te dwie kwestie są z sobą silnie związane, na ogół bowiem im niższy poziom analizy, tym mniejsza dostępność i większy stopień ogólności danych. W podejściu scen przyjmuje się, że im niższy jest poziom analizy, tym lepiej, bo dokładniej, trafniej i rzetelniej. Nie zawsze jednak uzyskanie wystarczająco dokładnych danych na odpowiednio niskim poziomie będzie możliwe i badacz może być zmuszony poszukać odpowiedniego kompromisu. 


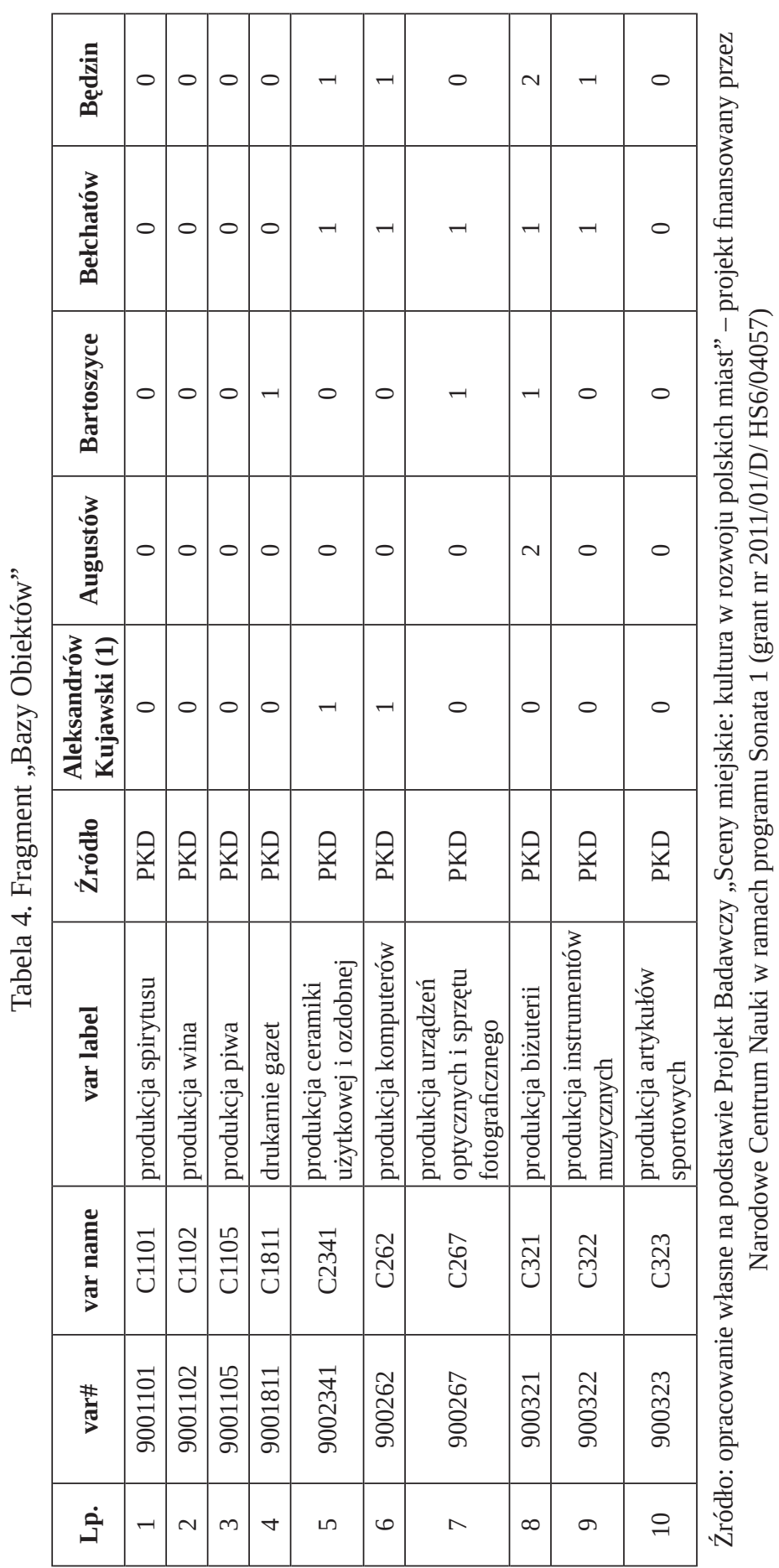


Tymczasem wybór poziomu analizy istotnie wpływa na otrzymany obraz charakteru kulturowego miasta. Porównanie wyników otrzymanych na poziomie miasta w Stanach Zjednoczonych, Polsce i Hiszpanii wskazywało na podstawowe podobieństwa w trendach rozwoju scen, jednakże analizy na niższym poziomie wskazywały na istotną odmienność kulturowej dynamiki polskich miast (Klekotko i Navarro, 2015). Podobnie uwzględnienie miast różnej wielkości przyniesie odmienne wyniki. Wyzwaniem jest ponadto porównywalność z założenia podobnych jednostek przestrzennych: inne są wielkości „dużych miast” w różnych krajach, podobnie jak różne są wielkości obszarów oznaczonych kodami pocztowymi w USA (w Polsce zresztą również) czy dzielnice polskich miast. Trzeba o tym pamiętać, kiedy podejmuje się próby porównań.

Dane do Bazy Obiektów pozyskać można z dwóch źródeł: rejestru działalności gospodarczych (REGON w Polsce, Business Register w USA) oraz książek telefonicznych (Polskie Książki Telefoniczne PKT w Polsce, Yellow Pages w USA). Każde z nich ma swoje wady i zalety. Rejestr REGON jest oficjalną bazą podmiotów prowadzących działalność gospodarczą na terenie Rzeczypospolitej Polskiej i spełnia warunki obiektywności. Każdy podmiot prowadzący działalność ma obowiązek dokonania rejestracji i posiadania numeru REGON. Największą słabością tej bazy są jednak zbyt szerokie kategorie klasyfikacji działalności gospodarczej, które mało mówią o charakterze kulturowym oferowanych przez dany podmiot dóbr lub usług. Działalność ta jest ponadto w rejestrze REGON nadreprezentowana, bo choć na przedsiębiorcach spoczywa obowiązek rejestracji każdej nowej działalności, to rezygnacja z prowadzenia jednej działalności przy zachowaniu działalności innego rodzaju, również zgłoszonej w rejestrze, często nie zostaje odnotowana. Przykładowo przedsiębiorca X w dniu rejestracji swojej firmy zgłasza działalność poligraficzną i handel materiałami biurowymi, a w rzeczywistości sprzedaje wyłącznie tusze do drukarek. Rejestrowanie działalności „na zapas” jest dość popularnym zjawiskiem i poleganie na „głównej działalności”, zgłoszonej w dniu rejestracji, nie chroni nas przed błędem nadreprezentacji. Polskie Książki Telefoniczne dysponują z kolei znacznie węższymi kategoriami działalności, stanowią jednak mniej wiarygodne źródło danych. Znajdziemy w nich tylko te podmioty, które zdecydowały się opłacić swoją obecność na stronach PKT. Tym samym rozmaite podmioty gospodarcze są $\mathrm{w}$ tej bazie niedoreprezentowane.

Aby wykorzystać zalety obu źródeł i zniwelować ich wady, warto połączyć obie bazy danych. Należy wtedy opracować plik przejściowy, tak zwany crosswalk, który posłuży do połączenia baz. Polega on na tym, 
że poszczególne kategorie działalności dostępne w Polskich Książkach Telefonicznych przypisuje się zgodnie z definicjami Polskiej Klasyfikacji Działalności (PKD) do odpowiedniej kategorii wykazu REGON. W ten sposób np. „działalności gastronomicznej” przypisać można restauracje chińskie, restauracje greckie i tym podobne, których adresy możemy znaleźć na stronach PKT. Następnie łączy się obie bazy w ten sposób, że uwzględnia się liczebności wszystkich obiektów pochodzących z bazy PKT oraz bazy REGON, przy czym od liczby przedsiębiorstw w danej klasie REGON odejmuje się liczebności przypisanych im obiektów pochodzących z PKT. Aby posłużyć się przykładem: na potrzeby realizowanych w polskich miastach badań od całkowitej liczby podmiotów prowadzących „działalność gastronomiczną” w danej jednostce przestrzennej odejmowaliśmy całkowitą liczbę restauracji chińskich, pizzerii, barów mlecznych itd. Do bazy wprowadziliśmy wszystkie typy placówek gastronomicznych obecnych w bazie PKT wraz z ich liczebnościami oraz ogólną kategorię „działalność gastronomiczna”, której liczebność była różnicą między całkowitą liczbą takich podmiotów w rejestrze REGON a całkowitą liczbą placówek gastronomicznych, o których dane pozyskaliśmy z PKT. W ten sposób powstała Baza Obiektów przedstawiona w formie tabeli, w której boczku znajdowały się poszczególne typy obiektów, w główce badane jednostki przestrzenne, a w komórkach liczebności poszczególnych obiektów w każdej jednostce. Dzięki opisanemu zabiegowi łączenia danych pochodzących z różnych źródeł udało nam się zebrać możliwie najbardziej dokładne dane na temat prowadzonej w miastach działalności. Kategoria „bar mleczny” daje nam znacznie dokładniejszy obraz charakteru prowadzonej działalności i jej klienteli niż ogólna kategoria „działalność gastronomiczna”, dlatego opisany zabieg był absolutnie konieczny.

Wybrane obiekty poddaje się następnie kodowaniu. Jest to zdecydowanie najbardziej czasochłonny etap badań, który zajmuje wiele miesięcy. Do kodowania angażuje się zespół kilku lub kilkunastu koderów, którym wręcza się instrukcję zawierającą definicje operacyjne analizowanych wymiarów oraz szczegółowe instrukcje procedury kodowania. Koderzy przyjmują rolę sędziów kompetentnych, od których oczekuje się dogłębnego zrozumienia kulturowej istoty analizowanych praktyk konsumpcji oraz definiujących je wymiarów. Ich zadaniem jest przydzielenie każdej zmiennej odpowiedniej wagi na każdym z piętnastu wymiarów; przyjmując, że w analizach uwzględnia się 300 zmiennych, sędziowie kompetentni muszą podjąć 4500 decyzji, od których zależeć będą wyniki analiz. Kodowanie przeprowadza się w arkuszu Excel, w boczku którego umieszcza się kodowane obiekty, 
a w główce 15 wymiarów scen. Warto wykonać podwójne kodowanie, z których jedno przeprowadza się „wymiarami”, kiedy badacz przesuwa się w arkuszu „,pionowo”, wypełniając najpierw wszystkie komórki jednej kolumny, a drugie „obiektami”, kiedy badacz przesuwa się w arkuszu poziomo, wypełniając pojedyncze wiersze i nadając każdemu obiektowi wagę na kolejnych wymiarach. Kodowanie dobrze jest prowadzić w falach po maksymalnie 25 obiektów tygodniowo. Po zakończeniu każdej fali należy omówić wątpliwości i trudności związane z postrzeganiem kulturowego znaczenia poszczególnych obiektów i rozumieniem definicji wymiarów. Przydatne są do tego notatki wykonywane przez koderów w procesie nadawania wag. Po zakodowaniu wszystkich obiektów należy dokonać analizy zgodności ocen, która wskaże zmienne o rozbieżnych kodach. Rozbieżne oceny należy następnie przeanalizować i poddać grupowej dyskusji. Na podstawie komentarzy i notatek ze spotkań należy odtworzyć sposób myślenia, jakim kierowano się przy nadawaniu wag, i ustalić źródła rozbieżności. Gdy wyjaśnione zostają wszelkie wątpliwości i uzyskuje się porozumienie w sprawie każdego kodu, proces nadawania wag można uznać za zakończony. Powstaje w ten sposób Baza Kodów, którą wraz z Bazą Obiektów wykorzystuje się w obliczeniach Performance Score, polegających na „skrzyżowaniu” obu baz, np. z wykorzystaniem tabel przestawnych w arkuszu Excel (tab. 5 i 6).

Nie sposób nie zauważyć istotnych słabości wybranego sposobu postępowania. Wątpliwości może budzić sama konstrukcja przyjętych wymiarów, a więc zaproponowana „gramatyka scen” powstała w północnoamerykańskim kontekście kulturowym na gruncie doświadczeń tamtejszych miast poprzemysłowych. Z jednej strony nie wszystkie wymiary „,pracują” jednakowo dobrze w rozmaitych kulturowych kontekstach, z drugiej zaś - porozumienie co do ich treści może pozostawać wątpliwe. Inaczej mówiąc, nie tylko inne obiekty mogą być postrzegane jako „charyzmatyczne” w Stanach Zjednoczonych, inne w Japonii, a jeszcze inne w Hiszpanii - samo pojęcie charyzmy może być tam odmiennie rozumiane! Dostosowanie liczby i treści wymiarów do warunków historyczno-kulturowych badanych miast uniemożliwiałoby jednak porównawcze analizy. Druga wątpliwość dotyczy zastosowania metody sędziów kompetentnych, która ma swoje istotne ograniczenia związane przede wszystkim z nieuniknionym subiektywizmem i kulturowym „bagażem” sędziów. Już sam dobór sędziów, cechujących się określonymi kompetencjami kulturowymi, może okazać się decydujący dla dalszych analiz. Ważne jest, by sędziowie nie tylko znali i rozumieli koncepcję społeczeństwa poprzemysłowego oraz sam język, którym opisano założenia 


\begin{tabular}{|c|c|c|c|c|c|}
\hline шz!ןеuo!̣ey & N & $m$ & $\sim$ & $\sim$ & \\
\hline omisüed & $m$ & $m$ & $m$ & $m$ & \\
\hline 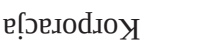 & $m$ & $m$ & $\checkmark$ & $m$ & \\
\hline 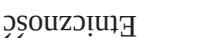 & $m$ & $m$ & $m$ & $m$ & \\
\hline шz!ןеуот & $m$ & $m$ & $m$ & $m$ & \\
\hline 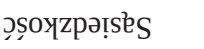 & $m$ & $m$ & $m$ & $m$ & \\
\hline шz!ןеш.ло & $m$ & $m$ & $m$ & $m$ & 3 \\
\hline ınошрі5 & $\nabla$ & $m$ & ص & $m$ & \\
\hline 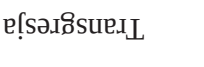 & $m$ & $m$ & $m$ & $m$ & \\
\hline 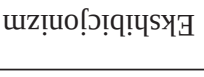 & $\nabla$ & $m$ & مص & $m$ & \\
\hline ешzК.лечכ & $m$ & $m$ & $\nabla$ & $\checkmark$ & \\
\hline 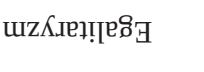 & N & $m$ & $\sim$ & $m$ & 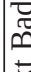 \\
\hline 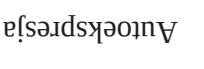 & $m$ & $\nabla$ & $m$ & $\nabla$ & $=$ \\
\hline 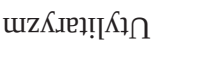 & $N$ & $\sim$ & $m$ & $\sim$ & \\
\hline е؟ฺКре.І & N & $m$ & $m$ & $m$ & \\
\hline оңрода & $\underset{\lambda}{2}$ & $\stackrel{\partial}{\lambda}$ & $\underset{\gamma}{2}$ & $\underset{\gamma}{\partial}$ & 3 \\
\hline Гәqе І Іе & 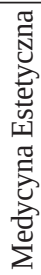 & 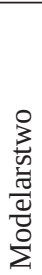 & 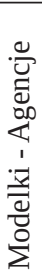 & 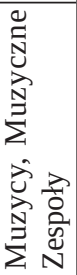 & 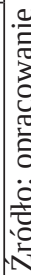 \\
\hline 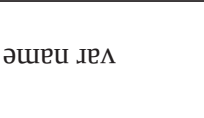 & 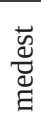 & 曷 & 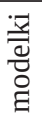 & 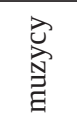 & \\
\hline 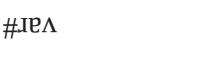 & 㞩 & $\begin{array}{l}\infty \\
\text { ᄋ } \\
\end{array}$ & 今) & 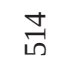 & \\
\hline
\end{tabular}

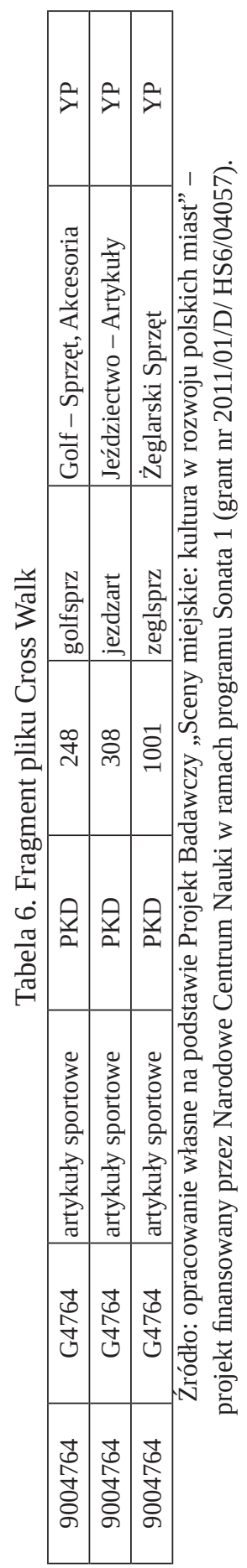


teorii scen, ale również byli zdolni do socjologicznej, naukowo obiektywnej refleksji nad kulturą polskiego społeczeństwa. Z drugiej jednak strony, choć taka strategia wyboru sędziów pozwalała maksymalizować trafność teoretyczną kodowania i jego możliwy „obiektywizm”, to jednak w pewnym sensie może ograniczać trafność empiryczną. Nie możemy przecież założyć, że „Zwykli śmiertelnicy” w ten sam sposób odbierają i wartościują poszczególne praktyki konsumpcji. Możemy przyjąć, że ich własne doświadczenia, gusta i wartości rzutują na sposób, w jaki postrzegają kodowane praktyki konsumpcji. Co dla jednej osoby może być już transgresyjne, dla innej jest jeszcze tradycjonalistyczne. Zapewne lepszą pod tym względem metodą nadawania wag analizowanym obiektom byłoby przeprowadzenie wywiadów z użytkownikami poszczególnych obiektów i próba odtworzenia motywacji, celów i wartości, które kierują określonymi praktykami konsumpcji. Trudno sobie jednak wyobrazić skalę takiego przedsięwzięcia.

\section{"Coś za coś", czyli nieuniknioność kompromisów i nadzieja na rozwój - zakończenie}

Przyjęta w teorii scen strategia pomiaru może budzić wątpliwości i zastrzeżenia, z których najważniejsze dotyczą subiektywizmu w doborze zmiennych i ich kodowaniu metodą sędziów kompetentnych oraz ograniczonej dostępności wystarczająco szczegółowych i dokładnych danych. Trudno się z tymi zastrzeżeniami nie zgodzić. Wiele miejskich fenomenów kulturowych o mniejszej skali wymyka się statystycznym analizom: choć można je zaobserwować za pomocą metod etnograficznych, nie znajdują one odzwierciedlenia w obliczanych wskaźnikach (por. Klekotko i Navarro, 2015). Wybór strategii badawczej zawsze jest jednak kompromisem: godzimy się na pewne ułomności, aby wykorzystać zalety niedostępne innym metodom. Ilościowo zorientowani badacze kulturowi miasta dla zaproponowanego przez teorię scen podejścia nie znajdują dziś alternatywy. Ważne jest jednak, by mieć świadomość ograniczeń przyjętej strategii, zachować czujność i dokładać wszelkich wysiłków, aby słabości te minimalizować, poszukując rozwiązań pozwalających rozwijać i udoskonalać metody.

Rozwiązaniem dylematu wyboru obiektów byłoby określenie przez teorię scen stałego, wspólnego dla wszystkich zestawu zmiennych (Klekotko i Navarro, 2018). Ustalenie takiego zestawu okazuje się jednak dość trudne, gdyż w różnych krajach, poza wspólnymi dla wszystkich formami konsumpcji, odnajdujemy także te specyficzne dla danej kultury. Przykładem mogą być 
kluby flamenco w Hiszpanii, bardzo typowe zwłaszcza dla miast południowych, których nie sposób pominąć w analizie ich charakteru kulturowego, a których próżno oczekiwać np. w Polsce, choć i na północy Hiszpanii mogą one okazać się dość egzotyczne. Wypracowanie uniwersalnej listy zmiennych jest jednak możliwe. Jednym z rozwiązań jest zawężenie listy zmiennych tylko do tych obiektów, które występują we wszystkich kontekstach kulturowych, i pominięcie obiektów specyficznych. Taka strategia, choć zdecydowanie najprostsza w zastosowaniu, nie pozwala jednak na wierne oddanie obrazu charakteru kulturowego badanych jednostek. Znacznie trafniejszą, ale też bardziej pracochłonną i wymagającą strategią jest rozszerzenie listy w taki sposób, by uwzględniała nie tylko wspólne dla wszystkich amenities, ale i wszystkie specyficzne dla różnych krajów kategorie.

Trudniejszą do pokonania przeszkodą w utworzeniu zestawu zmiennych okazuje się stopień szczegółowości danych, różny w różnych krajach. O ile amerykańscy badacze znajdą na swoich yellow pages tak wąsko zdefiniowane kategorie kawiarń jak Starbucks czy „kawa na wynos”, o tyle badacz polskich miast musi zadowolić się ogólną kategorią „kawiarnie”, gdyż ani REGON, ani Polskie Książki Telefoniczne nie oferują wystarczająco wąskich kategorii, które pozwoliłyby na wysoce precyzyjne zakodowanie obiektów (a nie ulega przecież wątpliwości, że sieciowa kawiarnia Starbucks służy realizacji zupełnie innych wartości niż niszowa, alternatywna kawiarnia z kawą fair trade). Naturalnie, możliwe jest wypracowanie listy kategorii dzielących się na bardziej dokładne podkategorie obiektów, jednakże różny poziom „czułości” zmiennych wykorzystywanych w różnych krajach będzie utrudniał porównania. Jedynym wyjściem w takich wypadkach jest, jak się zdaje, zmniejszenie owej „czułości” do wspólnego mianownika i porównywanie mniej czytelnych obrazów.

Również ograniczenia metody sędziów kompetentnych, subiektywizmu w nadawaniu obiektom wag oraz różnic kulturowych mają szansę stać się motorem rozwoju przyjętej perspektywy. Rzetelne i systematyczne dyskusje nad rozbieżnościami i wątpliwościami w kodowaniu pozwalają odkryć raison d'être pojmowania kulturowych wymiarów, odtworzyć logikę myślenia i schematy postrzegania aplikowane przez osoby kodujące, a tym samym dotrzeć do istoty kulturowych mechanizmów kształtowania się charakteru miasta. Dlatego też te najbardziej praco- i czasochłonne etapy warto powtarzać. Ciągłe powroty do tych etapów procesu wydają się nieuniknione i niezbędne, aby wypracować rzetelne i trafne narzędzie pomiaru scen, które pozwoli uzyskać wyniki najbardziej odpowiadające rzeczywistości społeczno-kulturowej analizowanych miast. 
Wypracowanie rozwiązań pozwalających udoskonalić strategię pomiaru scen i przezwyciężyć jej słabości wymaga współpracy i wymiany doświadczeń badawczych uczonych z jak największej liczby krajów. Taka międzynarodowa współpraca rozwijana jest od kilku lat w ramach Scenes Working Group skupionej wokół Terry’ego N. Clarka z Uniwersytetu Chicagowskiego. Pozostaje więc dzielić się swoimi doświadczeniami badawczymi, czekać na rezultaty współpracy i mieć nadzieję na dopracowanie tej niezwykle interesującej i wartościowej perspektywy.

\section{Literatura}

Borer, M.I. (2006). The Location of Culture: The Urban Culturalist Perspective. City and Community, 5(2), 173-197.

Brooks, D. (2000). Bobos in Paradise: The New Upper Class and Howe They Got There. New York: Simon and Schuster.

Chatterton, P., Hollands, R. (2002). Theorising urban playscapes: Producing, regulating and consuming youthful nightlife city spaces. Urban Studies, 39(1), 96-116.

Clark, T.N. (2003a). The City as an Entertainment Machine. Oxford: Elsevier.

Clark, T.N. (2003b). Urban amenities: Lakes, opera and juice bars. Do they drive development? W: T.N. Clark (red.), The City as an Entertainment Machine, Oxford: Elsevier.

Clark, T.N. (2007). Making culture into magic: How can it bring tourist and residents? International Review of Public Administration, 12(1), 13-26.

Clark, T.N., Lloyd, R., Wong, K.K., Jaiun, P. (2001). Amenities drive urban growth? Journal of Urban Affairs, 24(5), 493-515.

Florida, R. (2002a). Bohemia and economic geography. Journal of Economic Geography, 2, 55-71.

Florida, R. (2002b). The economic geography of talent. Annals of American Geographers, 92(4), 743-755.

Florida, R. (2002c). The Rise of the Creative Class. New York: Basic Books.

Gieryn, T.F. (2000). A space for sociology. Annual Review of Sociology, 26, 463-496.

Glaeser, E., Kolko, J., Saiz, A. (2001). Consumer city. Journal of Economic Geography, $1,27-50$.

Judd, D.R., Fainstein, S.S. (1999). The Tourist City. New Heaven: Yale University Press.

Kaple, D.A., Morris, L., Riukin-Fush, Z., Dimaggio, L. (1996). Data on Arts Organizations: A Review and Needs Assessments, with Design Implications (working paper 1). Princeton: Centre for Arts and Cultural Policy Studies, Princeton University Press.

Klekotko, M., Navarro, C.J. (red.). (2015). Wymiary kulturowe polskich miast i miasteczek. Kraków: Wydawnictwo Uniwersytetu Jagiellońskiego.

Klekotko, M., Navarro, C.J. (2018). Manual for Scenes Research, paper presented at RC 03 session on „Urban Scenes”. Toronto: World Congress of International Sociological Association (typescript). 
Klekotko, M., Navarro, C.J., Silver, D., Clark, T.N. (2015). Wymiary i charakter kulturowy miasta. W: M. Klekotko, C.J. Navarro (red.), Wymiary kulturowe polskich miast i miasteczek (ss. 13-60). Kraków: Wydawnictwo Uniwersytetu Jagiellońskiego.

Landry, C. (2006a). Lineages of creative city. Research of Journal for Creative Cities, 1(1), $15-23$.

Landry, C. (2006b). The Art of City Making. London: Earthscan.

Lloyd, R. (2007). Neo-bohemia: Art and Commerce in the Postindustrial City. New York: Routledge.

Lucchini, F. (2002). La culture au service des villes. Paris: Economica.

Markusen, S. (2006). Urban Development and the Politics of Creative Class: Evidence from the Study of Artists. Environment and Planning, 38, 1921-1940.

Navarro, C.J., Guerrero, G., Mateos, C., Muñoz, L. (2012). Escenas culturales, desigualdades y gentrificación en grandes ciudades españolas. Los casos de Barcelona, Bilbao, Madrid y Sevilla. W: J. Cucó (red.), Metamorfosis urbanas (ss. 109-132). Barcelona: Icaria.

Page, S. (1995). Urban Tourism. London: Routledge.

Rothfield, L. (1999). Cultural Policy Studies?!: A Guide for Perplexed Humanists (working paper). Chicago: Cultural Policy Center, University of Chicago.

Schuster, J.N. (2002). Informing Cultural Policy: The Research and Information Infrastructure. Bristol: Centre for Urban Policy Research.

Silver, D., Clark, T.N. (2016). Scenescapes: How Qualities of Place Shape Social Life. Chicago: University of Chicago Press.

Silver, D., Clark, T.N., Graziul, Ch. (2011). Scenes, innovation and urban development. W: D.E. Anderson, A.E. Anderson, Ch. Mellander (red.), Handbook of Creative Cities (ss. 229-258). Cheltenham-Northampton: Edward Elgar Publishing.

Silver, D., Clark, T.N., Navarro, C.J. (2010). Scenes: social context in an age of contingency. Social Forces, 88(5), 2293-2324.

Silver, D., Clark, T.N., Rothfield, L. (2007). A Theory of Scenes. Chicago: University of Chicago (typescript).

Zukin, S. (1995). The Culture of Cities. London: Blackwell. 